\title{
First report of Palaeomystella tibouchinae Becker \& Adamski, 2008 (Lepidoptera: Coleophoridae: Momphinae) in Rhynchanthera grandiflora (Melastomataceae) in Brazilian rupestrian fields of Espinhaço mountain range
}

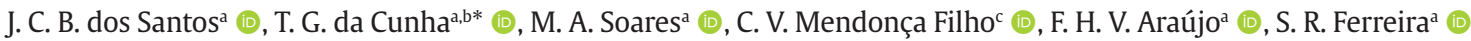 \\ and R. S. Silva ${ }^{\mathrm{a}}$ (1) \\ aUniversidade Federal dos Vales do Jequitinhonha e Mucuri Diamantina, Departamento de Agronomia, MG, Brasil \\ 'Instituto Federal de Educação, Ciência e Tecnologia de Minas Gerais, Campus Bambuí, Departamento de Ciências Agrárias, Bambuí, MG, Brasil \\ 'Universidade Federal dos Vales do Jequitinhonha e Mucuri Diamantina, Departamento de Ciências Biológicas, MG, Brasil
}

Ecological interactions can be defined as the population phenomena that occur between different species, such as competition, mutualism, and predation (e.g. herbivory and parasitism) (Nakazawa, 2020). The interaction between plants belonging to the family Melastomaceae and galling insects, mainly belonging to the order Lepidoptera, is still inadequately studied and reported. Galls in Melastomaceae species of plants have mainly been reported to be caused by the insects of the order Diptera, family Cecidomyiidae (Cintra et al., 2020). The family Melastomataceae includes thousands of known plant species, such as Rhynchanthera grandiflora (Aubl.) (CNCFLORA, 2012; Freiberg et al., 2020; Konzmann et al., 2020).

Rhynchanthera grandiflora is a shrub/sub-shrub that grows up to $2 \mathrm{~m}$ in height, and it is commonly found in the humid and open areas of several Brazilian biomes (CNCFLORA, 2012). This species is on the red list of threatened flora (SIBBR, 2020), and there are few reports on its interaction with galling insects. These interactions form an important component of biodiversity and may be strongly influenced by the species-specific traits (Stone and Schonrogge, 2003; Giron et al., 2016). The interactions between galling insects and their hosts provide them food and a protective environment against adverse climatic conditions and natural enemies (Price et al., 1987; Stone and Schonrogge, 2003; Giron et al., 2016).

The galling insect Palaeomystella tibouchinae Becker \& Adamski, 2008 (Lepidoptera: Momphidae) was identified in Brazil as a new species attacking the plants of Tibouchina barbigera (Naudin) Baillon (Melastomataceae) (Becker and Adamski, 2008). Interactions between P. tibouchinae and $R$. grandiflora have not been reported so far. Therefore, in this study, we aimed to report the interaction between gall-inducing $P$. tibouchinae in $R$. grandiflora plants. This information can be useful for future studies on ecological interactions between these species.
This study was conducted in a rupestrian field area in Diamantina, Minas Gerais state (18²12,404'S, $\left.43^{\circ} 36^{\prime} 042^{\prime \prime} \mathrm{W}\right)$ at Serra do Espinhaço, Brazil. This region was declared as a biosphere reserve by UNESCO and as a Globally Important Agricultural Heritage System (GIAHS) by the UN Food and Agricultural Organization (Brasil, 2018; FAO, 2020). An important and exclusive type of vegetation that covers the mountains of this region includes the rupestrian fields. It is formed by shrubby vegetation, prone to fire, along with patches of cerrado and forests (Silveira et al., 2016) and with rock fields and mountain pastures, that remains constant in Diamantina (Soares et al., 2021). The local climate is classified as Cwb based on the Köppen classification system, which is characterized by subtropical dry winter plateaus and rainy summers.

Ten $R$. grandiflora shrubs were inspected in this study, of which 4 possessed galls on them (Figure 1a). A total of six galls were collected from each shrub (Figure $1 \mathrm{~b}$ ), which were packed in plastic pots, transferred to the Universidade Federal dos Vales do Jequitinhonha e Mucuri (UFVJM), in Diamantina, Minas Gerais state, Brazil, and stored in an air conditioned room with temperature $25 \pm 2^{\circ} \mathrm{C}$, relative humidity $70 \pm 10 \%$, and photoperiod of $12 \mathrm{~h}$. A total of four galls were opened, and a larva (Figure 1c) and a pupae (Figure 1d) were spotted in two of them. The other two galls were empty. A total of 20 galls were preserved until the adults emerged (after 22 days) (Figure 1e). After the emergence of adults, five non-sexed adults were used for further identification. The insects were identified by an insect taxonomist, Dr. Vitor O. Becker (Instituto Uiraçu), based on the key and identification system proposed by Becker and Adamski (2008) as Palaeomystella tibouchine (Figure 1e).

The species $P$. tibouchine was first described in 2008 and the available information about its ecological interaction with host species is limited. Therefore, documenting the occurrence of gall formation by $P$. tibouchine in plant 


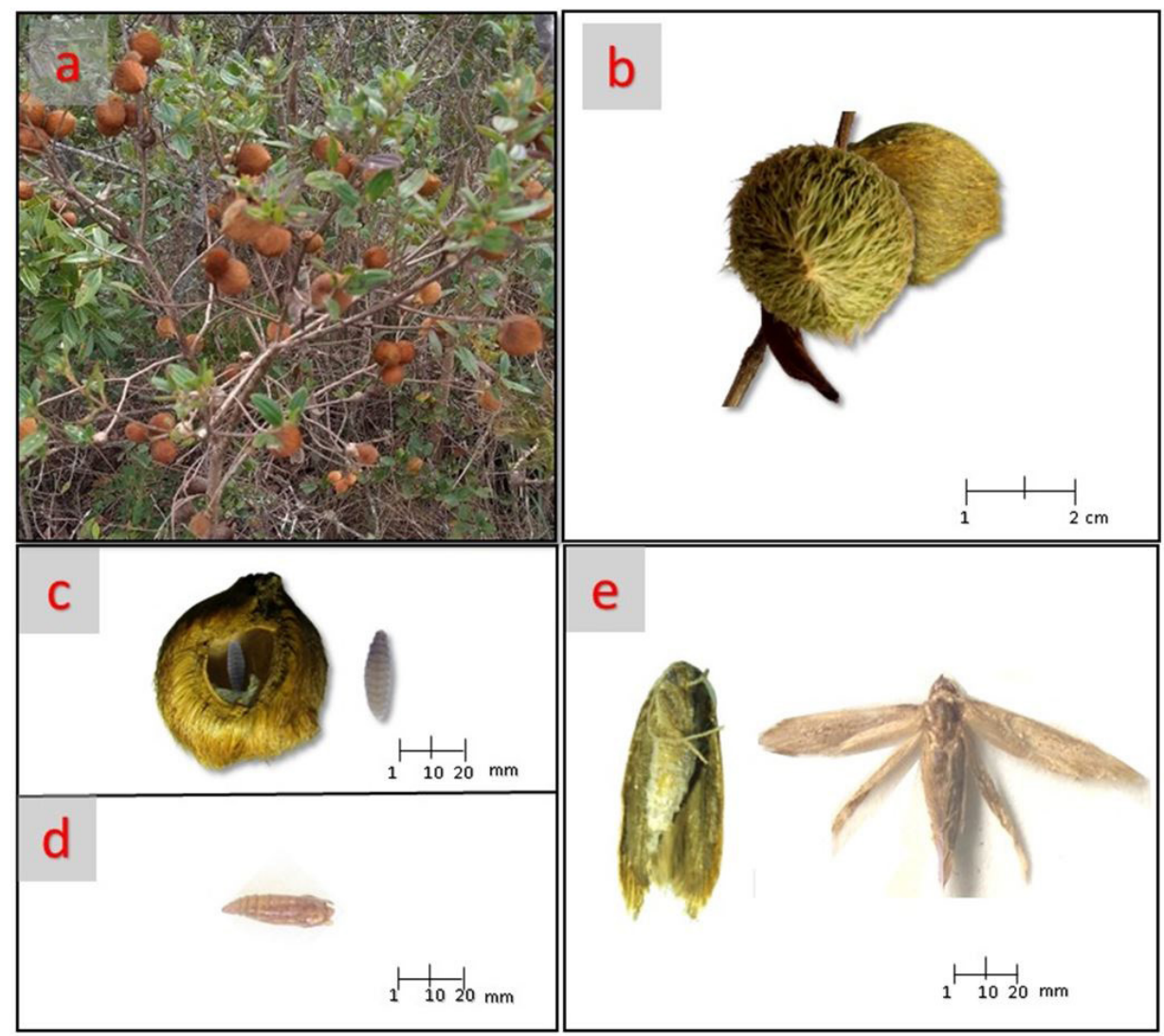

Figure 1. Rhynchanthera grandiflora with galls (a), representative image of galls (b); larva inside a gall (c), pupae (d), and adults (e) of Palaeomystella tibouchinae.

species, $R$. grandiflora, is an important scientific effort to advance knowledge about the species and their ecological interactions.

Here, we report, for the first time, the gall-inducing species $P$. tibouchine on $R$. grandiflora, and this represents a starting point for future ecological studies on the interaction between lepidoterans and plant species of the Melastomataceae family.

\section{Acknowledgements}

The authors would like to thank: Conselho Nacional de Desenvolvimento Científico e Tecnológico - CNPq, Coordenação de Aperfeiçoamento de Pessoal de Ensino Superior - CAPES Finance Code 001, Fundação de Amparo à Pesquisa do Estado de Minas Gerais - FAPEMIG and the Universidade Federal dos Vales do Jequitinhonha e Mucuri for for the financial support provided and institutional support.

\section{References}

BECKER, V.O. and ADAMSKI, D., 2008. Three new cecidogenous Palaeomystella Fletcher (Lepidoptera, Coleophoridae, Momphinae) associated with Melastomataceae in Brazil. Revista
Brasileira de Entomologia, vol. 52, no. 4, pp. 647-657. http:// dx.doi.org/10.1590/S0085-56262008000400017.

CINTRA, F.C.F., ARAÚJO, W.S., MAIA, V.C., URSO-GUIMARÃES, M.V., VENÂNCIO, H., ANDRADE, J.F., CARNEIRO, M.A.A., ALMEIDA, W.R. and SANTOS, J.C., 2020. Plant-galling insect interactions: a data set of host plants and their gall-inducing insects for the Cerrado. Ecology, vol. 101, no. 11, pp. e03149. http://dx.doi. org/10.1002/ecy.3149. PMid:32737876.

FOOD AND AGRICULTURE ORGANIZATION OF THE UNITED NATIONS - FAO, 2020 [viewed 25 March 2020]. Designation of the first Brazilian GIAHS site in the Southern Espinhaço Range, Minas Gerais [online]. Rome: FAO. Avalable from: http://www.fao. org/giahs/news/detail-events/en/c/1264691/

FREIBERG, M., WINTER, M., GENTILE, A., ZIZKA, A., MUELLNERRIEHL, A.N., WEIGELT, A. and QIRTH, C., 2020. LCVP, The Leipzig catalogue of vascular plants, a new taxonomic reference list for all known vascular plants. Scientific Data, vol. 7, no. 1, pp. 416. PMid:33243996.

GIRON, D., HUGUET, E., STONE, G.N. and BODY, M., 2016. Insectinduced effects on plants and possible effectors used by galling and leaf-mining insects to manipulate their host-plant. Journal of Insect Physiology, vol. 84, pp. 70-89. http://dx.doi.org/10.1016/j. jinsphys.2015.12.009. PMid:26723843.

KONZMANN, S., HILGENDORF, F., NIESTER, C., RECH, A.R. and LUNAU, K., 2020. Morphological specialization of heterantherous Rhynchanthera grandiflora (Melastomataceae) accommodates pollinator diversity. Plant Biology, vol. 22, no. 4, pp. 583-590. http://dx.doi.org/10.1111/plb.13102. PMid:32112502. 
NAKAZAWA, T., 2020. Species interaction: revisiting its terminology and concept. Ecological Research, vol. 35, no. 6, pp. 1106-1113. http://dx.doi.org/10.1111/1440-1703.12164.

PRICE, P.W., FERNANDES, G.W. and WARING, G.L., 1987. Adaptive nature of insect galls. Environmental Entomology, vol. 16, no. 1, pp. 15-24. http://dx.doi.org/10.1093/ee/16.1.15.

SILVEIRA, F., NEGREIROS, D., BARBOSA, N., BUISSON, E., CARMO, F., CARSTENSEN, D., CONCEIÇÃO, A., CORNELISSEN, T., ECHTERNACHT, L., FERNANDES, G., GARCIA, Q., GUERRA, T., JACOBI, C., LEMOS-FILHO, J., STRADIC, S., MORELLATO, L., NEVES, F., OLIVEIRA, R., SCHAEFER, C. and VIANA, P., 2016. Ecology and evolution of plant diversity in the endangered campo rupestre: a neglected conservation priority. Plant and Soil, vol. 403, no. 1/2, pp. 129-152. http://dx.doi.org/10.1007/s11104-015-2637-8.

SISTEMA DE INFORMAÇÃO SOBRE A BIODIVERSIDADE BRASILEIRA - SIBBR, 2020 [viewed 25 March 2020]. Lista Vermelha de Ameaça da Flora Brasileira 2014 do CNCFlora [online]. SIBBR. Available from: https://specieslist.sibbr.gov.br/ speciesListItem/list/drt1565629935045?fq=kvp+genus\%3 ARhynchanthera\&max $=10$
SOARES, M.A., FAUSTINO-JÚNIOR, W., OLIVEIRA, D.K.S., CALDEIRA, Z.V., SILVA, E.T.L., ASSIS-JÚNIOR, S.L., ZANUNCIO, J.C. and ZANUNCIO, A.J.V., 2021. Edessa rufomarginata (Hemiptera: Pentatomidae) feeding on Solanum lycocarpum (Solanaceae) in rupestrian fields of the Brazilian Cerrado biome. Brazilian Journal of Biology = Revista Brasileira de Biologia, vol. 82, pp. e235839. http://dx.doi.org/10.1590/1519-6984.235839. PMid:34133550.

STONE, G.N. and SCHÖNROGGE, K., 2003. The adaptive significance of insect gall morphology. Trends in Ecology \& Evolution, vol. 18, no. 10, pp. 512-522. http://dx.doi.org/10.1016/S01695347(03)00247-7.

CNCFLORA, 2012 [viewed 25 March 2020]. Rhynchanthera grandiflora [online]. Centro Nacional de Conservação da Flora. Avalable from: http://www.cncflora.jbrj.gov.br/portal/pt-br/profile/ Rhynchanthera\%20grandiflora.

BRASIL. MINISTÉRIO DO MEIO AMBIENTE - MMA, 2018 [viewed 25 March 2021]. Espinhaço, Biosphere Reserve of the Mountain: Phase 2 [online]. MaB-UNESCO, Belo Horizonte. Available from: https://www.mma.gov.br/images/arquivo/80252/RBSE_\%20_ PROPOSAL-PHASE\%202_final_document_\%2028.09.2018_v1.pdf 